\title{
Serum Biomarkers for the Prediction of Hepatocellular Carcinoma
}

\author{
José D. Debes ${ }^{1,2, *}$, Pablo A. Romagnoli ${ }^{3}{ }^{\complement}$, Jhon Prieto ${ }^{4}$, Marco Arrese ${ }^{5} \odot$, Angelo Z. Mattos ${ }^{6}$, André Boonstra ${ }^{1, *}$ \\ and on behalf of the ESCALON Consortium ${ }^{1}$
}

1 Department of Gastroenterology and Hepatology, Erasmus MC Rotterdam, 3015 CE Rotterdam, The Netherlands

2 Department of Medicine, University of Minnesota, Minneapolis, MN 55455, USA

3 Centro de Investigaciones en Medicina Translacional "Severo Amuchastegui" (CIMETSA), Instituto Universitario de Ciencias Biomédicas de Córdoba (IUCBC), Córdoba 5016, Argentina; pablo.romagnoli@iucbc.edu.ar

4 Centro de Enfermedades Hepaticas y Digestivas, Bogota CS412, Colombia; jhonprieto@hotmail.com

5 Department of Gastroenterology, Escuela de Medicina, \& Centro de Envejecimiento y Regeneración (CARE), Pontificia Universidad Católica de Chile, Santiago 8330077, Chile; marrese@med.puc.cl

6 Graduate Program in Medicine: Hepatology, Universidade Federal de Ciências da Saúde de Porto Alegre, Porte Alegre 90050-170, Brazil; angeloz@ufcspa.edu.br

* Correspondence: debes003@umn.edu (J.D.D.); p.a.boonstra@erasmusmc.nl (A.B.)

Citation: Debes, J.D.; Romagnoli, P.A.; Prieto, J.; Arrese, M.; Mattos, A.Z.; Boonstra, A.; Serum Biomarkers for the Prediction of Hepatocellular Carcinoma. Cancers 2021, 13, 1681. https://doi.org/10.3390/ cancers13071681

Academic Editor: Adam E. Frampton

Received: 12 January 2021

Accepted: 28 March 2021

Published: 2 April 2021

Publisher's Note: MDPI stays neutral with regard to jurisdictional claims in published maps and institutional affiliations.

\begin{abstract}
Hepatocellular carcinoma (HCC) is a leading cause of global cancer death. Major etiologies of HCC relate to chronic viral infections as well as metabolic conditions. The survival rate of people with HCC is very low and has been attributed to late diagnosis with limited treatment options. Combining ultrasound and the biomarker alpha-fetoprotein (AFP) is currently one of the most widely used screening combinations for HCC. However, the clinical utility of AFP is controversial, and the frequency and operator-dependence of ultrasound lead to a variable degree of sensitivity and specificity across the globe. In this review, we summarize recent developments in the search for non-invasive serum biomarkers for early detection of HCC to improve prognosis and outcome for patients. We focus on tumor-associated protein markers, immune mediators (cytokines and chemokines), and micro-RNAs in serum or circulating extracellular vesicles and examine their potential for clinical application.
\end{abstract}

Keywords: hepatocellular carcinoma; biomarker; cytokines; microRNA; tumor marker

\section{Introduction}

Hepatocellular carcinoma (HCC) is the most common primary liver malignancy. According to current epidemiological data, it is the fourth leading cause of cancer mortality worldwide, ranking among the most commonly diagnosed cancer in both genders [1,2]. HCC generally develops in the context of liver cirrhosis of any cause. However, it is particularly linked to infections with the hepatitis B virus (HBV) or hepatitis $\mathrm{C}$ virus (HCV) and alcoholic or nonalcoholic fatty liver disease (NAFLD), which are the most common underlying etiologies [2-4].

HCC-related mortality has steadily increased and almost tripled in the United States since the 1980s, where it is the fastest rising cause of cancer-related deaths with more than 39,000 cases and 29,000 deaths in 2018 [5]. Importantly, according to World Health Organization estimates, globally, more than one million patients will die from liver cancer in 2030 [6]. These data underscore the magnitude of the HCC-associated disease burden, which, despite the advances made in its surveillance and diagnosis, is still often diagnosed at advanced stages, precluding timely and eventually curative therapeutic intervention resulting in poor prognosis. Thus, early HCC diagnosis is critical in order to improve patient outcomes. Proposed strategies for early detection of HCC include adherence to surveillance programs in populations at risk and the development of sensitive and specific 
diagnostic biomarkers $[7,8]$. HCC surveillance comprising of ultrasound screening every six months is recommended for all patients with cirrhosis, but, as mentioned above, tailoring HCC surveillance programs may be necessary for certain diseases (i.e., HBV and NAFLD) so to include at-risk non-cirrhotic patients [9]. In this regard, non-cirrhotic HBV-infected individuals are advised to undergo surveillance in a range of ages based on geographic location across the globe. Participation in surveillance for HCC in cirrhotic individuals has been regarded as suboptimal, with some studies in the United States and Europe showing that less than $40 \%$ of patients with cirrhosis undergo proper HCC surveillance [10,11]. A large study from our group involving over 1300 HCC cases in South America found that less than $50 \%$ of HCCs were diagnosed via surveillance [12]. Although several issues contribute to such low participation in surveillance, the lack of a reliable blood biomarker that is easy to detect and that provides a high degree of sensitivity and specificity is certainly among the most important contributing factors. Due to the diverse genetic nature of HCC and the existence of different underlying liver diseases, no biomarker has progressed to the point of implementation. Underlying liver disease is indeed a point of contention as in processes like viral hepatitis; there is an ongoing inflammatory cascade that obscures the approach to identifying immune or inflammatory markers that could be related to the tumor. With new advancing technologies, which allow us to detect low expressing proteins, RNAs and genetic material in endovesicles, a number of new circulating biomarkers are currently under study $[8,13]$. In this review, we aim to summarize the available information and recent developments on HCC biomarkers detected in serum, classified as protein, miRNA and immune biomarkers (Figure 1), which may impact early HCC diagnosis and, therefore, implementation of appropriate management that can optimize prognosis in HCC. We aim to present what are considered to be the most advanced, important or novel biomarkers and not to present an exhaustive review.

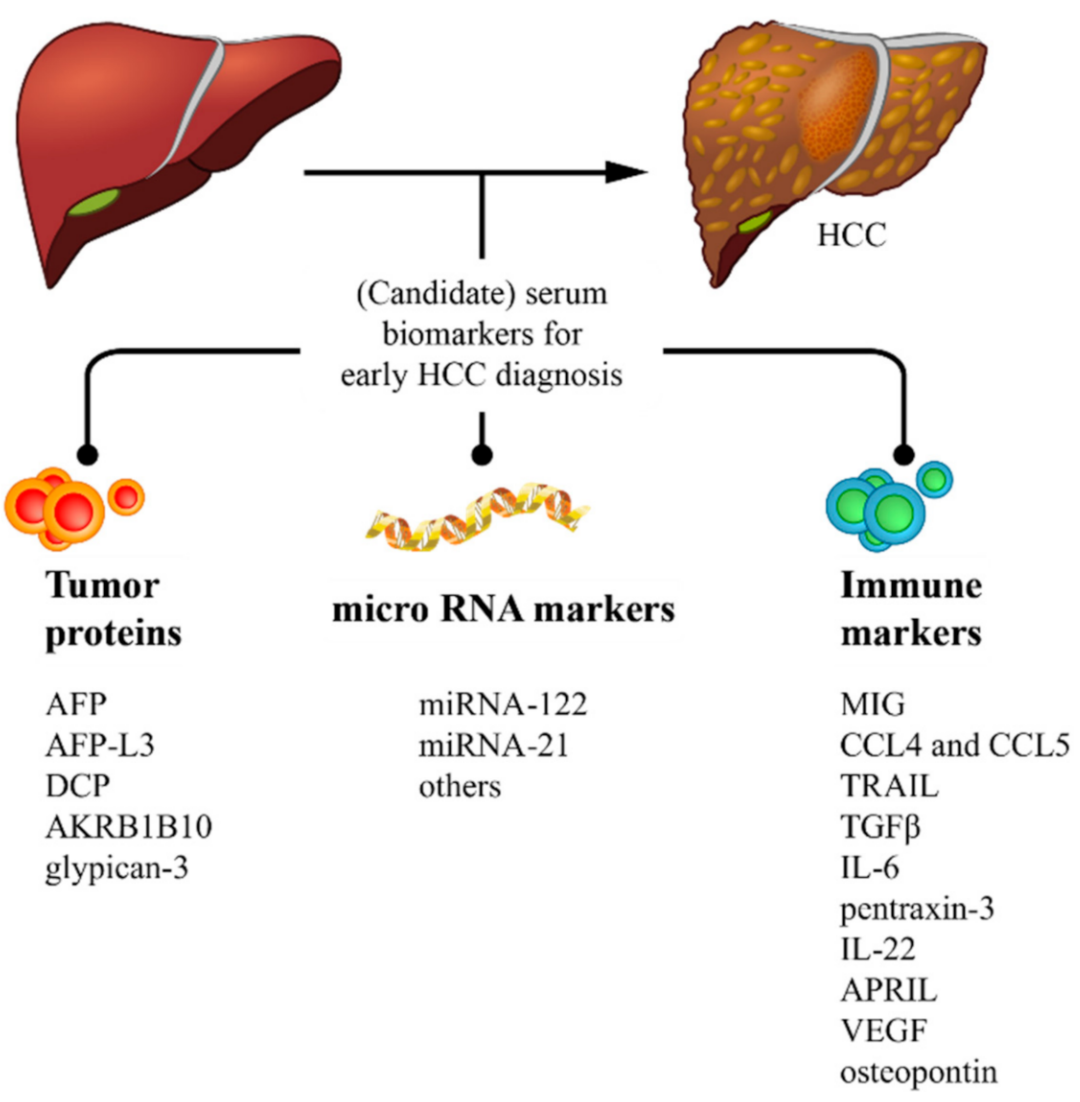

Figure 1. Graph summarizing different classifications of biomarkers discussed in the review. For abbreviations, please see the main text 


\section{Protein Biomarkers}

Alpha-fetoprotein (AFP) is the most commonly used biomarker for the surveillance and diagnosis of HCC. Nevertheless, current guidelines either do not recommend its use or make it optional in addition to ultrasound $[14,15]$. The main reasons that prevent the widespread use of AFP are concerning the specificity and limited sensitivity it has in detecting early-stage HCC, with a considerable number of HCC that do not have elevated serum AFP levels. Elevated AFP serum levels are also observed in some patients with viral hepatitis, cholangiocarcinoma and other tumors, leading to false-positive results for HCC diagnosis [16]. However, a meta-analysis on HCC surveillance has demonstrated that ultrasound alone is less sensitive than ultrasound associated with AFP (sensitivity of $45 \%$ versus $63 \%$, relative risk of 0.81 for early-stage HCC in patients with cirrhosis) [17]. Also, a model based on the pattern of increase of AFP over time identified patients at high risk of developing HCC as early as 15 years before the diagnosis so that these individuals could be monitored more intensively than their counterparts. The area under the receiver operating characteristic curve (AUROC) for AFP ranged from 0.73 to 0.83 in different cohorts [18].

As the performance of AFP is suboptimal, many other serum biomarkers are under investigation. Two markers that received much attention are a glycoform of AFP, lectinbinding AFP-3 (AFP-L3), and des-gamma-carboxyprothrombin (DCP), also known as prothrombin induced by vitamin $\mathrm{K}$ absence-II (PIVKA-II), which is a non-functional protein produced by HCC. A randomized controlled trial evaluating HCC surveillance through ultrasound with or without AFP, AFP-L3 and DCP has demonstrated that the association of these biomarkers with ultrasound increases sensitivity while decreasing specificity [19]. In another study in which samples from four prospective Korean cohorts were analyzed, AFP performed better than AFP-L3 and DCP up to 12 months prior to the diagnosis of HCC. When biomarkers were combined, the association between AFP and AFP-L3 had the best performance both at 12 and at 6 months before the diagnosis. At the moment of the diagnosis, AFP combined with AFP-L3 performed comparably as the combination of all three biomarkers. Regarding early-stage HCC, results were also favorable to AFP combined with AFP-L3. Finally, adding AFP and AFP-L3 to ultrasound improved the sensitivity $(94.3 \%)$, despite decreasing specificity $(82.7 \%)$ [20].

A score, which includes these biomarkers is the GALAD score, an acronym for gender, age, AFP-L3, AFP and DCP, which resulted in AUROC values of more than 0.88 irrespective of the HCC disease stage [21]. In a North American validation cohort, the score had an AUROC of 0.95 for HCC detection, while ultrasound had an AUROC of 0.82 , a superiority that remained for early-stage as well as very early-stage HCC. In the same study, the GALADUS score was described, adding ultrasound findings to the GALAD score. The GALADUS score had AUROCs of 0.98 for any-stage HCC and 0.97 for early-stage HCC [22]. In patients with nonalcoholic steatohepatitis, the GALAD score demonstrated sensitivity and specificity with an AUROC of 0.96 to identify patients with any stage HCC Importantly, these high AUROC values were observed in NASH patients with and without cirrhosis (0.93 and 0.98 , respectively). The GALAD score also identified individuals who would develop HCC as early as 1.5 years before the diagnosis. When early-stage HCC was concerned, the score had a sensitivity of $86.2 \%$ and a specificity of $90.9 \%$ [23].

In addition, different classes of serum protein biomarkers have been described. The LCR1 model identifies patients without cirrhosis who are at risk of developing primary liver cancer. The parameters that makeup LCR1 include serum apolipoprotein A1, haptoglobin, gamma-glutamyltranspeptidase, alpha2-macroglobulin, age and gender. In addition, a second model has been described, the LCR2 model, which is used to follow individuals identified by LCR1 and patients with cirrhosis; LCR2 includes the same variables combined with AFP. AUROCs were 0.78 for LCR1 and 0.87 for LCR2, and LCR2 performed better than AFP (AUROC = 0.72) [24].

Another panel of serum biomarkers for early diagnosis of HBV-related HCC consists of five plasma proteins (P5). The P5 panel includes osteopontin, growth and differentiation factor 15 (GDF15), neuron-specific enolase, thrombin receptor activator for peptide 5 
and osteoprotegerin. The panel outperformed AFP in the diagnosis of early-stage HCC (AUROC $=0.85-0.91$ for P5 and 0.54-0.59 for AFP, according to different cutoff values and different validation cohorts). Furthermore, P5 predicted HCC development approximately one year before being clinically diagnosed [25]. Regarding osteopontin alone as a marker, it was demonstrated in a different study that it performs better than AFP (AUROCs of 0.85 and 0.68 , respectively), a benefit that remained for early-stage HCC; this is further discussed below [26].

An interesting study from Asia evaluated serum levels of aldo-keto reductase family 1 member B10 (AKR1B10) as a putative HCC biomarker. The biomarker detected earlystage HCC with a sensitivity of $61 \%$ and a specificity of $86 \%$ and performed better than AFP alone. However, the highest performance was achieved by the combination of both biomarkers (AUROC $=0.94)$. Such findings were similar in a validation cohort [27].

Finally, glypican-3 is a biomarker that has been evaluated in many studies. Glypican-3 is a transmembrane proteoglycan anchored to the cell membrane, highly expressed by some HCC tumors and can be detected in serum. Two recent meta-analyses have been published in which the value of serum glypican-3 levels in the diagnosis of HCC was evaluated. In the first study, glypican-3 performed similar to AFP (AUROCs of 0.78 and 0.79 , respectively), while their combination had good accuracy $($ AUROC $=0.94)$ [28] in discriminating HCC from liver cirrhosis. The second meta-analysis evaluated the performance of glypican-3, Golgi protein 73 and AFP levels. These three biomarkers combined had an AUROC of 0.95 and performed better than any biomarker alone or any pair of biomarkers [29].

\section{MicroRNA Biomarkers}

Micro RNAs (miRNAs) are small non-coding RNA molecules of approximately 22-24 nucleotides in length that regulate gene expression and are critically involved in the processes of liver development during embryogenesis, liver homeostasis and liver pathophysiology [30]. miRNAs can be secreted into the extracellular space and are found circulating in various body fluids as either part of extracellular vesicles or exosomes (exo) or associated with circulating proteins [31]. Dysregulated expression of miRNAs has been demonstrated in various tumors, including the most common, such as lung, prostate, colon, breast and also liver cancers, and has been shown to affect the regulation of the activity of oncogenes and tumor suppressor genes, thereby directly influencing carcinogenesis [32]. As a consequence of their dysregulated expression, circulating miRNAs have been studied as potential biomarkers for cancer, including for HCC, detected using non-invasive techniques in serum or plasma [33]. miRNAs can be measured by molecular biology methods, like quantitative polymerase chain reaction (PCR), microarray or RNAseq analysis. Moreover, because miRNAs are small molecules, have a high sequence homology among family members and low abundance, new methods, such as those based on nanomaterials, are being developed for highly sensitive detection of miRNAs [34].

In a study from Korea [35], the expression levels of circulating miRNA were determined in serum of patients with HCC and in controls individuals with chronic HBV or liver cirrhosis. In this study, four exosome-derived miRNAs were found to be of interest (exomiR-10b-5p, exo-miR-18a-5p, exo-miR-215-5p, and exo-miR-940) when examining serum samples from 90 patients with HCC and 60 controls with chronic liver disease. In particular, exo-miR-10b-5p appeared as a promising biomarker for early-stage HCC with an AUROC of 0.93 , a sensitivity of $90.7 \%$ and specificity of $75.0 \%$ [35]. Another set of miRNAs, exo-miR25-3p, exo-miR-1269a, exo-miR-4661-5p, and exo-miR-4746-5p with increased expression in HCC were found by selecting driver oncogenic miRNAs using analysis of miRNAs expression profiles from three different RNA sequencing datasets of human HCC [36]. In particular, serum exo-miR-4661-5p could detect HCC at all stages with AUROC of 0.92; even at early-stage HCC, the AUROC remained at 0.92. Furthermore, a panel composed of both exo-miR-4661-5p and exo-miR-4746-5p was able to detect early-stage HCC with an AUROC of 0.95 , a sensitivity of $81.8 \%$ and a specificity of $91.7 \%$. A retrospective study from China [37] identified a miRNA classifier containing seven circulating miRNAs (mIR-29a, 
mIR-29c, mIR-133a, mIR-143, mIR-145, mIR-192 and mIR-505) in serum that could detect HBV-induced HCC. This classifier showed higher accuracy than AFP (when using the 20 $\mathrm{ng} / \mathrm{mL}$ cutoff) to distinguish individuals with HCC from individuals with chronic HBV or liver cirrhosis [37]. Interestingly, this study also established the ability of the miRNA classifier to predict preclinical HCC before diagnosis in a surveillance program with HBV. The miRNA panel detected 8 cases of HCC at 12 months before diagnosis ( 8 out of 27), whereas AFP could detect only 2 cases. A recent study evaluated the use of circulating miRNAs to identify HCC by analyzing serum samples from 353 HCC patients, 46 chronic hepatitis patients, and 93 patients with liver cirrhosis [38]. This study found that a combination of 8 miRNAs, miR-320b, miR-663a, miR-4448, miR-4651, miR-4749-5p, miR-6724-5p, miR6877-5p, and miR-6885-5p could discriminate HCC from at-risk control samples (chronic hepatitis and/or cirrhosis) with a diagnostic value AUC of 0.99 , a sensitivity of $97.7 \%$ and specificity of $94.7 \%$. This model is proposed to detect $98 \%$ of stage I HCC cases [38]. The diagnostic value of this miRNA panel is superior to the diagnostic values achieved by either serum AFP, the GALAD score and the GALADUS score [20-22].

Since the various studies that examined the value of miRNA as an HCC biomarker examined either cell-free or exosomal derived miRNAs, a study involving 72 patients with HCC, 72 cirrhotic controls and 72 patients with HBV compared the diagnostic value and showed that a microRNA panel (miRNA-26a, miRNA-29c, and miRNA-21) in exosomes provided better diagnostic value for patients with HCC than circulating cell-free miRNAs among different groups [39]. Along the same line, it has been reported that the number of detected miRNA in plasma outnumbers the number detected in paired serum samples and that the expression levels in plasma were found to be higher than in serum, indicating that standardization of the biological material is crucial [40]. These observations may also, at least partially, explain that no research group has found the same discriminating set of miRNAs, with the exception of known dysregulated miRNAs in liver disease like miRNA-122 [41,42] or miRNA-21 [43,44] as candidates for early-stage HCC detection. Also, Table 1, which summarizes a series of microRNAs that are not further discussed in the review, clearly shows that most studies that evaluate circulating miRNAs as potential biomarkers for HCC detection were conducted using Asian cohorts, which are generally characterized by a high-frequency of HBV-induced HCC, and no or small numbers of HCC induced by HCV, alcohol or NAFLD. In addition, these studies were conducted involving small groups of patients and have yet to be validated within large cohort of patients [35,36,43-47].

Overall, circulating miRNAs appear to be promising biomarkers to detect earlystage HCC. To move this field further, longitudinal studies should be carried out, including larger cohorts to validate the diagnostic performance obtained by different sets of miRNAs in cross-sectional studies across different standardized detection platforms and disease etiologies.

Table 1. Summary of published literature on miRNA evaluation as a biomarker for hepatocellular carcinoma (HCC).

\begin{tabular}{ccccc}
\hline miRNA & Etiology & Country & Source & Study Subjects \\
\hline $\begin{array}{c}\text { miR-21, miR-106b, } \\
\text { miR-125b, miR-182, } \\
\text { miR-224 }\end{array}$ & Multiple & China & Serum & $\begin{array}{c}\text { 66 HCC patients and } \\
82 \text { healthy controls }\end{array}$ \\
\hline $\begin{array}{c}\text { miR-21, miR-26a } \\
\text { miR-101 }\end{array}$ & Multiple & China & Serum & $\begin{array}{c}52 \text { HCC patients, } \\
\text { [2 chronic hepatitis patients } \\
\text { and 43 healthy controls }\end{array}$ \\
\hline miR-88 & [49] & $\begin{array}{c}\text { 80 HCC patients, 45 liver } \\
\text { cirrhosis patients, } \\
45 \text { chronic HBV patients and } \\
43 \text { healthy controls }\end{array}$ \\
\hline
\end{tabular}


Table 1. Cont.

\begin{tabular}{|c|c|c|c|c|c|}
\hline miRNA & Etiology & Country & Source & Study Subjects & Reference \\
\hline $\begin{array}{l}\text { miR-375, miR-10a, } \\
\text { miR-122, miR-423 }\end{array}$ & Multiple & China & Serum & $\begin{array}{l}149 \text { HCC patients and } \\
149 \text { controls }\end{array}$ & {$[51]$} \\
\hline $\begin{array}{l}\text { miR-122, miR-125b, } \\
\text { miR-145, miR-192, } \\
\text { miR-194, miR-29a, } \\
\text { miR-17-5p, miR-106a }\end{array}$ & Multiple & China & Serum exosomes & $\begin{array}{l}80 \text { HCC patients and } \\
30 \text { healthy controls }\end{array}$ & [47] \\
\hline $\begin{array}{l}\text { miR-122, } \\
\text { miR-224 }\end{array}$ & $\mathrm{HCV}$ & Egypt & Plasma & $\begin{array}{c}40 \mathrm{HCC} \text { patients related to } \\
\mathrm{HCV}, 40 \text { chronic HCV } \\
\text { patients and } 20 \text { healthy } \\
\text { volunteers }\end{array}$ & [52] \\
\hline $\begin{array}{l}\text { miR-21, } \\
\text { miR-122 }\end{array}$ & Multiple & India & Serum & $\begin{array}{l}50 \text { HCC patients, } 25 \text { chronic } \\
\text { hepatitis patients, } 25 \text { liver } \\
\text { cirrhosis patients and } \\
10 \text { healthy individuals }\end{array}$ & [53] \\
\hline $\begin{array}{l}\text { miR-122, miR-148a, } \\
\text { miR-1246 miR-486, } \\
\text { miR-584 }\end{array}$ & Multiple & China & Serum exosomes & $\begin{array}{c}68 \text { HCC patients, } 53 \text { liver } \\
\text { cirrhosis patients, } 50 \text { chronic } \\
\text { hepatitis patients, } \\
64 \text { controls }\end{array}$ & [54] \\
\hline $\begin{array}{l}\text { miR-19a, miR-296, } \\
\text { miR-195, miR-192, } \\
\text { miR-34a, miR-146a }\end{array}$ & $\mathrm{HCV}$ & Egypt & Serum & $\begin{array}{c}112 \mathrm{HCC} \text { patients related to } \\
\mathrm{HCV}, 125 \text { chronic HCV } \\
\text { patients and } 42 \text { healthy } \\
\text { controls }\end{array}$ & [55] \\
\hline $\begin{array}{c}\operatorname{miR}-375 \\
\operatorname{miR}-199 a-3 p\end{array}$ & Multiple & China & Serum & $\begin{array}{l}78 \text { HCC patients and } \\
156 \text { healthy controls }\end{array}$ & [56] \\
\hline $\begin{array}{l}\text { miR214-5p, miR125b, } \\
\text { miR-1269 miR-375 }\end{array}$ & $\mathrm{HCV}$ & Egypt & Serum & $\begin{array}{c}224 \mathrm{HCC} \text { patients related to } \\
\mathrm{HCV}, 250 \text { chronic HCV } \\
\text { patients and } 84 \text { healthy } \\
\text { controls }\end{array}$ & [57] \\
\hline $\operatorname{miR}-4463$ & $\mathrm{HBV}$ & China & Serum & $\begin{array}{c}45 \text { HCC patients and } \\
45 \text { controls }\end{array}$ & [58] \\
\hline mIR-106b & Not mentioned & China & Serum & 335 HCC patients & [59] \\
\hline $\begin{array}{l}\text { miR-10b, miR-106b, } \\
\text { miR-181a }\end{array}$ & Multiple & China & Serum & $\begin{array}{l}27 \text { HCC patients, } 31 \text { chronic } \\
\text { liver disease patients and } \\
50 \text { healthy controls }\end{array}$ & [60] \\
\hline miR-23a & Not mentioned & Egypt & Serum & $\begin{array}{c}57 \text { HCC patients, } 57 \text { liver } \\
\text { cirrhosis patients and } 57 \\
\text { healthy controls }\end{array}$ & [61] \\
\hline $\begin{array}{l}\operatorname{miR}-10 b-5 p \\
\text { miR-215-5p }\end{array}$ & HBV & Korea & Serum exosomes & $\begin{array}{l}90 \text { HCC patients, } 60 \text { chronic } \\
\text { liver disease patients and } \\
28 \text { healthy controls }\end{array}$ & [35] \\
\hline miR-301 & $\mathrm{HCV}$ & Egypt & Plasma & $\begin{array}{l}42 \mathrm{HCC} \text { patients related to } \\
\mathrm{HCV}, 48 \text { chronic HCV } \\
\text { patients (all with liver } \\
\text { cirrhosis) and } 40 \text { healthy } \\
\text { controls }\end{array}$ & {$[62]$} \\
\hline $\begin{array}{c}\text { miR-1246, } \\
\text { miR-101-3p } \\
\text { miR-106b-3p }\end{array}$ & Multiple & Italy & Plasma & $\begin{array}{c}\text { cohort 1:7 HCC patients, } \\
10 \text { liver cirrhosis patients } \\
\text { and } 7 \text { controls; } \\
\text { cohort 2:9 HCC patients and } \\
6 \text { liver cirrhosis patients } \\
\text { cohort 3:22 HCC patients } \\
\text { and } 11 \text { healthy controls }\end{array}$ & [45] \\
\hline
\end{tabular}


Table 1. Cont.

\begin{tabular}{|c|c|c|c|c|c|}
\hline miRNA & Etiology & Country & Source & Study Subjects & Reference \\
\hline miR-224 & HBV & China & Serum & 182 HCC patients & [63] \\
\hline $\begin{array}{l}\text { miR-150, } \\
\text { miR-182 }\end{array}$ & $\mathrm{HCV}$ & Egypt & Serum & $\begin{array}{l}40 \text { HCC patients, } 40 \text { chronic } \\
\text { HCV patients ( } 20 \text { cirrhotic } \\
\text { and } 20 \text { non-cirrhotic) and } 40 \\
\text { healthy controls. }\end{array}$ & [64] \\
\hline $\begin{array}{l}\text { miR-122, miR-221, } \\
\text { miR-222 } \\
\text { miR-224 }\end{array}$ & $\mathrm{HBV}$ & China & Serum exosomes & $\begin{array}{l}20 \text { HCC patients, } 20 \text { chronic } \\
\text { HBV patients, and } 20 \text { liver } \\
\text { cirrhosis patients }\end{array}$ & [65] \\
\hline
\end{tabular}

\section{Immune Biomarkers}

Immunosurveillance, the recognition of tumor cells by leukocytes, has been welldescribed for many tumors and has changed the way to interpret the role of circulating immune markers in the setting of oncogenesis [66]. Hence, cytokines and chemokines induced upon recognizing cancerous lesions can be detected in serum or plasma of individuals at risk. This fact is highlighted in the formation of HCC, as the tumor usually arises in the setting of chronic hepatitis where a hyper-immune environment due to the continuous presence of an inflammatory response in the liver could lead to further alterations in measurable immune analytes during the transition from a liver nodule to HCC $[67,68]$. Our group recently identified a series of immune markers in serum of patients with hepatitis $C$ that were associated with the future development of HCC, even when cancer occurred up to two years later [67]. These markers include, among others, soluble highly immunoreactive proteins, such as MIG, interleukin (IL)-22 and IL-3, as well as vascular endothelial growth factor (VEGF) and tumor necrosis factor-related apoptosis-inducing ligand (TRAIL), which are related to the vascular formation and apoptosis modulation. The c-statistic for the correct prediction of HCC was $>0.90$ in four of these markers (MIG, IL-22, TRAIL, APRIL), which is defined as extraordinary and $>0.80$ in the rest. However, this study was performed in a small number of samples (13 subjects per group), and all samples were from HCV-infected individuals. It is likely that in other chronic infections, such as HBV, these immune markers would play a role in early HCC detection as well.

Tumor growth factor $\beta$ (TGF- $\beta$ ), a polyfunctional growth factor that has been shown to interact literally on all cell types by modulating cell proliferation, cell differentiation and even cell survival, also has potential as a biomarker for HCC. Mutations and differential expression of TGF- $\beta$ have been found to be altered in a variety of tumor types. Previous studies have shown that serum levels of TGF- $\beta$ are associated with HCC development, mainly in HCV-infected individuals [69]. However, other studies have addressed TGF- $\beta$ role as a biomarker in HCC in combination with the expression of other proteins or mRNA and not as a stand-alone biomarker [70]. Moreover, several of these studies have been performed in single-country populations without confirmation in other settings.

Osteopontin (OPN), a versatile cytokine, which mediates a wide array of biological functions in the immune and vascular system, has been reviewed before as a marker for a variety of tumors [71]. Several studies have shown increased serum and plasma levels of OPN in individuals with HCC compared to those with liver cirrhosis and/or chronic liver disease controls $[26,72,73]$. The majority of these studies were carried out in Asian cohorts, with a large multicenter study conducted using West-African and European cohorts replicating these findings [74]. In most studies, OPN has shown an AUROC of no less than 0.75 for HCC prediction. In contrast, the diagnostic efficacy of OPN in detecting early-stage HCC vs. non-HCC patients varied considerably depending on the study. Ge et al. [75] and Vongsuvanh et al. [76] reported an AUROC of 0.57 and 0.78, respectively, whereas Shang et al. reported an AUC of 0.73 [73]. Interestingly, a prospective evaluation in an Asian cohort of 115 patients with chronic liver disease at risk of HCC showed increased plasma OPN levels 24 months prior to diagnosis in 21 subjects who developed HCC [74]. 
Recently, serum pentraxin 3 also has been suggested as a candidate biomarker of HBV-induced HCC in a study from China [77]. Pentraxin 3 is a protein produced by multiple cell types, such as macrophages, monocytes, fibroblasts and endothelial cells in response to inflammatory signals (such as bacterial components or cytokines, such as TNF or IL-1), and as such, pentraxins behave as acute-phase proteins. Pentraxin 3 may also be involved in cancer development, although the underlying mechanisms are not well understood. Elevated pentraxin 3 levels have been reported in patients with acute liver injury, NASH and HCV, among others. Evaluating the serum pentraxin 3 levels in 107 patients with HCC in comparison to 159 chronic HBV and 99 cirrhotic patients demonstrated that pentraxin 3 was highly discriminative of AFP-negative and early-stage HCC, and the diagnostic performance of pentraxin 3 was superior to AFP. In fact, the AUC for pentraxin to discriminate early HCC from cirrhosis was 0.90 , while it was 0.68 for AFP, clearly suggesting the potential of pentraxin 3 as a biomarker for early HCC.

Chemokines play an important role as mediators of immune responses since they are instrumental in the recruitment and activation of leukocytes at the inflamed or injured location. The chemokines C-C motif ligand 4 (CCL4) and CCL5 bind to the same receptor, $\mathrm{C}-\mathrm{C}$ receptor 5 , which is expressed in effector and memory $\mathrm{T}$ cells, making this interaction critical in controlling chronic viral infections [78]. Only one study to date has evaluated serum levels of various chemokines in the context of HCC detection, and multivariate regression analysis found that serum CCL4 and CCL5 levels were higher in cirrhotics with HCC than cirrhotics without HCC $(n=78)$, making them interesting candidate diagnostic markers for HCC. The performance of CCL4 and CCL5 was comparable for HCC detection, with an AUROC for CCL5 of 0.72 and relatively high sensitivity of $71 \%$ and specificity of $68 \%[76]$.

VEGF, an angiogenic factor for vascular endothelial cells, is produced by many cell types, including tumor cells [79]. A Japanese study [80] involving HCV-infected individuals with HCC demonstrated that the AUROC for detection of HCC of VEGF was superior to that of AFP (AUROC of 0.98 versus 0.71, respectively) [80]. However, a study performed in Egypt, also in HCV-infected individuals (all genotype 4), did not detect serum VEGF differences among HCV patients who developed HCC and control HCV patients [81]. The recent longitudinal study from our group, mentioned above, identified serum VEGF as one out 12 immune mediators to be increased in HCV-induced HCC [67]. Despite a promising status, VEGF requires further investigation as a stand-alone marker for early or late HCC detection.

Multiple studies have shown a role for IL-6 in inflammation leading to liver cancer, and even gender disparities in HCC have been explained by the interrelation between estrogen and IL-6 [82]. Serum IL-6 has been shown to be increased in HCC patients compared to patients with chronic liver disease [83]. However, most studies have evaluated the performance of IL-6 in the setting of advanced HCC [84], but not during the early stages. Of note, IL-6 pretreatment levels did not associate with macrovascular invasion or extrahepatic spread, but some studies show a potential for this cytokine as a predictor to response to systemic therapy $[84,85]$. Moreover, cellular models have described decreased resistance to sorafenib by inhibiting IL-6-related pathways [85].

Growth differentiation factor 15 (GDF15), a member of the TGF- $\beta$ superfamily, has been shown to be elevated in HCC compared to controls in HBV- and HCV-positive Chinese cohorts [86]. Although this study initially raised promise about the perspectives of GDF15, a later study found increased serum levels of the immune analyte in HBV-related HCC and HCV-related HCC compared to either chronic viral infection, but no statistical difference when compared to cirrhotic patients [87]. Further studies performed in prospective cohorts are needed to assess the role of GDF15 in HCC as well as in non-viral hepatitis-related HCC.

\section{Conclusions}

One of the main factors related to the high mortality in HCC is the frequency of late diagnosis of this tumor. Despite attempts to implement surveillance strategies, adherence 
to surveillance programs has been reported to be low across the globe [88]. Peripheral biomarkers that are easily measured in serum or plasma are of critical need in the field of HCC. However, the tumor's genetic diversity has blunted efforts to discover reliable and specific proteins that could aid in the early detection of HCC. Moreover, the conundrum of liver diseases underlying the development of liver cirrhosis and hence HCC, such as viral hepatitis, create an immune imbalance that further obscures the ability to identify immune markers or peripherally expressed proteins that could assist in early detection. However, recent advances in techniques allowing the detection of multiple immune analytes, as well as the progress in quantifying microRNAs specific to the liver, have contributed to a change in balance that favors the proper implementation of biomarkers, which easily and effectively predict or diagnose early HCC. Moreover, new technologies that allow for exosome (endovesicles) assessment in relation to HCC detection will bring this field to new territories. It should be expected that in the next 5-10 years, the hepato-oncology community will have a broader spectrum of tools to predict HCC with a simple serum assessment.

Author Contributions: J.D.D. and A.B. conceptualization, writing and critical editing; P.A.R., A.Z.M., M.A. writing and critical editing, J.P., A.B. writing and figure-table conceptualization. All authors have read and agreed to the published version of the manuscript.

Funding: All authors are members of the European-Latin American ESCALON consortium, funded by the EU Horizon 2020 program, project number 825510. Partially funded by Fondo Nacional de Desarrollo Científico y Tecnológico grants 1191145 and Comisión Nacional de Investigación Científica y Tecnológica (CONICYT, AFB170005) to MA, the Robert Wood Johnson Foundation, AMFDP, and NIH-NCI R21 CA215883-01A1 to J.D.D.

Data Availability Statement: The data presented in this study are available on request from the corresponding author.

Conflicts of Interest: The authors declare no conflict of interest.

\section{References}

1. Villanueva, A. Hepatocellular Carcinoma. N. Engl. J. Med. 2019, 380, 1450-1462. [CrossRef] [PubMed]

2. Caines, A.; Selim, R.; Salgia, R. The Changing Global Epidemiology of Hepatocellular Carcinoma. Clin. Liver Dis. 2020, 24, 535-547. [CrossRef] [PubMed]

3. Anstee, Q.M.; Reeves, H.L.; Kotsiliti, E.; Govaere, O.; Heikenwalder, M. From NASH to HCC: Current concepts and future challenges. Nat. Rev. Gastroenterol. Hepatol. 2019, 16, 411-428. [CrossRef] [PubMed]

4. Levrero, M.; Zucman-Rossi, J. Mechanisms of HBV-induced hepatocellular carcinoma. J. Hepatol. 2016, 64, S84-S101. [CrossRef] [PubMed]

5. Bray, F.; Ferlay, J.; Soerjomataram, I.; Siegel, R.L.; Torre, L.A.; Jemal, A. Global cancer statistics 2018: GLOBOCAN estimates of incidence and mortality worldwide for 36 cancers in 185 countries. CA Cancer J. Clin. 2018, 68, 394-424. [CrossRef] [PubMed]

6. Howell, J.; Pedrana, A.; Schroeder, S.E.; Scott, N.; Aufegger, L.; Atun, R.; Baptista-Leite, R.; Hirnschall, G.; 't Hoen, E.; Hutchinson, S.J.; et al. A global investment framework for the elimination of hepatitis B. J. Hepatol. 2020. [CrossRef] [PubMed]

7. Singal, A.G.; Lampertico, P.; Nahon, P. Epidemiology and surveillance for hepatocellular carcinoma: New trends. J. Hepatol. 2020, 72, 250-261. [CrossRef]

8. Parikh, N.D.; Mehta, A.S.; Singal, A.G.; Block, T.; Marrero, J.A.; Lok, A.S. Biomarkers for the Early Detection of Hepatocellular Carcinoma. Cancer Epidemiol. Biomark. Prev. 2020. [CrossRef]

9. Yang, J.D.; Heimbach, J.K. New advances in the diagnosis and management of hepatocellular carcinoma. BMJ 2020, 371. [CrossRef]

10. Goldberg, D.S.; Taddei, T.H.; Serper, M.; Mehta, R.; Dieperink, E.; Aytaman, A.; Baytarian, M.; Fox, R.; Hunt, K.; Pedrosa, M.; et al. Identifying barriers to hepatocellular carcinoma surveillance in a national sample of patients with cirrhosis. Hepatology 2016. [CrossRef]

11. Edenvik, P.; Davidsdottir, L.; Oksanen, A.; Isaksson, B.; Hultcrantz, R.; Stål, P. Application of hepatocellular carcinoma surveillance in a European setting. What can we learn from clinical practice? Liver Int. 2015, 35, 1862-1871. [CrossRef]

12. Debes, J.D.; Chan, A.J.; Balderramo, D.; Kikuchi, L.; Gonzalez Ballerga, E.; Prieto, J.E.; Tapias, M.; Idrovo, V.; Davalos, M.B.; Cairo, F.; et al. Hepatocellular carcinoma in South America: Evaluation of risk factors, demographics and therapy. Liver Int. 2018, 38, 136-143. [CrossRef]

13. Beudeker, B.J.B.; Boonstra, A. Circulating biomarkers for early detection of hepatocellular carcinoma. Therap. Adv. Gastroenterol. 2020, 13. [CrossRef]

14. EASL. EASL Clinical Practice Guidelines: Management of hepatocellular carcinoma. J. Hepatol. 2018, 69, 182-236. [CrossRef] 
15. Heimbach, J.K.; Kulik, L.M.; Finn, R.S.; Sirlin, C.B.; Abecassis, M.M.; Roberts, L.R.; Zhu, A.X.; Murad, M.H.; Marrero, J.A. AASLD guidelines for the treatment of hepatocellular carcinoma. Hepatology 2018, 67, 358-380. [CrossRef]

16. Chan, S.L.; Mo, F.; Johnson, P.J.; Siu, D.Y.; Chan, M.H.; Lau, W.Y.; Lai, P.B.; Lam, C.W.; Yeo, W.; Yu, S.C. Performance of serum $\alpha$-fetoprotein levels in the diagnosis of hepatocellular carcinoma in patients with a hepatic mass. HPB 2014, 16, 366-372. [CrossRef]

17. Tzartzeva, K.; Obi, J.; Rich, N.E.; Parikh, N.D.; Marrero, J.A.; Yopp, A.; Waljee, A.K.; Singal, A.G. Surveillance Imaging and Alpha Fetoprotein for Early Detection of Hepatocellular Carcinoma in Patients With Cirrhosis: A Meta-analysis. Gastroenterology 2018, 154, 1706-1718.e1. [CrossRef]

18. Hughes, D.M.; Berhane, S.; Emily de Groot, C.A.; Toyoda, H.; Tada, T.; Kumada, T.; Satomura, S.; Nishida, N.; Kudo, M.; Kimura, T.; et al. Serum Levels of $\alpha$-Fetoprotein Increased More Than 10 Years Before Detection of Hepatocellular Carcinoma. Clin. Gastroenterol. Hepatol. 2020. [CrossRef]

19. Sherman, M.; Feld, J.; Yamada, H.; Mori, Y.; Janssen, H. A randomized controlled trial of US vs US + biomarkers for the diagnosis of hepatocellular carcinoma: An interim report. J. Hepatol. 2017, 66, S13. [CrossRef]

20. Choi, J.; Kim, G.A.; Han, S.; Lee, W.; Chun, S.; Lim, Y.S. Longitudinal Assessment of Three Serum Biomarkers to Detect Very Early-Stage Hepatocellular Carcinoma. Hepatology 2019, 69, 1983-1994. [CrossRef]

21. Johnson, P.J.; Pirrie, S.J.; Cox, T.F.; Berhane, S.; Teng, M.; Palmer, D.; Morse, J.; Hull, D.; Patman, G.; Kagebayashi, C.; et al. The detection of hepatocellular carcinoma using a prospectively developed and validated model based on serological biomarkers. Cancer Epidemiol. Biomark. Prev. 2014, 23, 144-153. [CrossRef]

22. Yang, J.D.; Addissie, B.D.; Mara, K.C.; Harmsen, W.S.; Dai, J.; Zhang, N.; Wongjarupong, N.; Ali, H.M.; Ali, H.A.; Hassan, F.A.; et al. GALAD Score for Hepatocellular Carcinoma Detection in Comparison with Liver Ultrasound and Proposal of GALADUS Score. Cancer Epidemiol. Biomark. Prev. 2019, 28, 531-538. [CrossRef]

23. Best, J.; Bechmann, L.P.; Sowa, J.P.; Sydor, S.; Dechêne, A.; Pflanz, K.; Bedreli, S.; Schotten, C.; Geier, A.; Berg, T.; et al. GALAD Score Detects Early Hepatocellular Carcinoma in an International Cohort of Patients With Nonalcoholic Steatohepatitis. Clin. Gastroenterol. Hepatol. 2020, 18, 728-735.e4. [CrossRef]

24. Poynard, T.; Peta, V.; Deckmyn, O.; Munteanu, M.; Moussalli, J.; Ngo, Y.; Rudler, M.; Lebray, P.; Pais, R.; Bonyhay, L.; et al. LCR1 and LCR2, two multi-analyte blood tests to assess liver cancer risk in patients without or with cirrhosis. Aliment. Pharmacol. Ther. 2019, 49, 308-320. [CrossRef]

25. Cheng, K.; Shi, J.; Liu, Z.; Jia, Y.; Qin, Q.; Zhang, H.; Wan, S.; Niu, Z.; Lu, L.; Sun, J.; et al. A panel of five plasma proteins for the early diagnosis of hepatitis B virus-related hepatocellular carcinoma in individuals at risk. EBioMedicine 2020, $52,102638$. [CrossRef]

26. Zhu, M.; Zheng, J.; Wu, F.; Kang, B.; Liang, J.; Heskia, F.; Zhang, X.; Shan, Y. OPN is a promising serological biomarker for hepatocellular carcinoma diagnosis. J. Med. Virol. 2020. [CrossRef]

27. Ye, X.; Li, C.; Zu, X.; Lin, M.; Liu, Q.; Liu, J.; Xu, G.; Chen, Z.; Xu, Y.; Liu, L.; et al. A Large-Scale Multicenter Study Validates Aldo-Keto Reductase Family 1 Member B10 as a Prevalent Serum Marker for Detection of Hepatocellular Carcinoma. Hepatology 2019, 69, 2489-2501. [CrossRef]

28. Xu, D.; Su, C.; Sun, L.; Gao, Y.; Li, Y. Performance of Serum Glypican 3 in Diagnosis of Hepatocellular Carcinoma: A meta-analysis. Ann. Hepatol. 2019, 18, 58-67. [CrossRef] [PubMed]

29. Zhao, S.; Long, M.; Zhang, X.; Lei, S.; Dou, W.; Hu, J.; Du, X.; Liu, L. The diagnostic value of the combination of Golgi protein 73, glypican-3 and alpha-fetoprotein in hepatocellular carcinoma: A diagnostic meta-analysis. Ann. Transl. Med. 2020, 8, 536. [CrossRef] [PubMed]

30. Niveditha, D.; Jasoria, M.; Narayan, J.; Majumder, S.; Mukherjee, S.; Chowdhury, R.; Chowdhury, S. Common and Unique microRNAs in Multiple Carcinomas Regulate Similar Network of Pathways to Mediate Cancer Progression. Sci. Rep. 2020, 10, 2331. [CrossRef] [PubMed]

31. Turchinovich, A.; Samatov, T.R.; Tonevitsky, A.G.; Burwinkel, B. Circulating miRNAs: Cell-cell communication function? Front. Genet. 2013, 4, 119. [CrossRef]

32. Croce, C.M. Causes and consequences of microRNA dysregulation in cancer. Nat. Rev. Genet. 2009, 10, 704-714. [CrossRef]

33. Arrese, M.; Eguchi, A.; Feldstein, A.E. Circulating microRNAs: Emerging biomarkers of liver disease. Semin. Liver Dis. 2015, 35, 43-54. [CrossRef]

34. Ye, J.; Xu, M.; Tian, X.; Cai, S.; Zeng, S. Research advances in the detection of miRNA. J. Pharm. Anal. 2019, 9, 217-226. [CrossRef]

35. Cho, H.J.; Eun, J.W.; Baek, G.O.; Seo, C.W.; Ahn, H.R.; Kim, S.S.; Cho, S.W.; Cheong, J.Y. Serum Exosomal MicroRNA, miR-10b-5p, as a Potential Diagnostic Biomarker for Early-Stage Hepatocellular Carcinoma. J. Clin. Med. 2020, 9, 281. [CrossRef]

36. Cho, H.J.; Baek, G.O.; Seo, C.W.; Ahn, H.R.; Sung, S.; Son, J.A.; Kim, S.S.; Cho, S.W.; Jang, J.W.; Nam, S.W.; et al. Exosomal microRNA-4661-5p-based serum panel as a potential diagnostic biomarker for early-stage hepatocellular carcinoma. Cancer Med. 2020, 9, 5459-5472. [CrossRef]

37. Lin, X.J.; Chong, Y.; Guo, Z.W.; Xie, C.; Yang, X.J.; Zhang, Q.; Li, S.P.; Xiong, Y.; Yuan, Y.; Min, J.; et al. A serum microRNA classifier for early detection of hepatocellular carcinoma: A multicentre, retrospective, longitudinal biomarker identification study with a nested case-control study. Lancet Oncol. 2015, 16, 804-815. [CrossRef] 
38. Yamamoto, Y.; Kondo, S.; Matsuzaki, J.; Esaki, M.; Okusaka, T.; Shimada, K.; Murakami, Y.; Enomoto, M.; Tamori, A.; Kato, K.; et al. Highly Sensitive Circulating MicroRNA Panel for Accurate Detection of Hepatocellular Carcinoma in Patients With Liver Disease. Hepatol. Commun. 2020, 4, 284-297. [CrossRef]

39. Lin, H.; Zhang, Z. Diagnostic value of a microRNA signature panel in exosomes for patients with hepatocellular carcinoma. Int. J. Clin. Exp. Pathol. 2019, 12, 1478-1487.

40. Foye, C.; Yan, I.K.; David, W.; Shukla, N.; Habboush, Y.; Chase, L.; Ryland, K.; Kesari, V.; Patel, T. Comparison of miRNA quantitation by Nanostring in serum and plasma samples. PLoS ONE 2017, 12, e0189165. [CrossRef]

41. Jin, Y.; Wong, Y.S.; Goh, B.K.P.; Chan, C.Y.; Cheow, P.C.; Chow, P.K.H.; Lim, T.K.H.; Goh, G.B.B.; Krishnamoorthy, T.L.; Kumar, R.; et al. Circulating microRNAs as Potential Diagnostic and Prognostic Biomarkers in Hepatocellular Carcinoma. Sci. Rep. 2019, 9, 10464. [CrossRef]

42. Mjelle, R.; Dima, S.O.; Bacalbasa, N.; Chawla, K.; Sorop, A.; Cucu, D.; Herlea, V.; Saetrom, P.; Popescu, I. Comprehensive transcriptomic analyses of tissue, serum, and serum exosomes from hepatocellular carcinoma patients. BMC Cancer 2019, 19, 1007. [CrossRef]

43. Tomimaru, Y.; Eguchi, H.; Nagano, H.; Wada, H.; Kobayashi, S.; Marubashi, S.; Tanemura, M.; Tomokuni, A.; Takemasa, I.; Umeshita, K.; et al. Circulating microRNA-21 as a novel biomarker for hepatocellular carcinoma. J. Hepatol. 2012, 56, 167-175. [CrossRef]

44. Sorop, A.; Iacob, R.; Iacob, S.; Constantinescu, D.; Chitoiu, L.; Fertig, T.E.; Dinischiotu, A.; Chivu-Economescu, M.; Bacalbasa, N.; Savu, L.; et al. Plasma Small Extracellular Vesicles Derived miR-21-5p and miR-92a-3p as Potential Biomarkers for Hepatocellular Carcinoma Screening. Front. Genet. 2020, 11, 712. [CrossRef]

45. Moshiri, F.; Salvi, A.; Gramantieri, L.; Sangiovanni, A.; Guerriero, P.; De Petro, G.; Bassi, C.; Lupini, L.; Sattari, A.; Cheung, D.; et al. Circulating miR-106b-3p, miR-101-3p and miR-1246 as diagnostic biomarkers of hepatocellular carcinoma. Oncotarget 2018, 9, 15350-15364. [CrossRef]

46. Elhendawy, M.; Abdul-Baki, E.A.; Abd-Elsalam, S.; Hagras, M.M.; Zidan, A.A.; Abdel-Naby, A.Y.; Watny, M.; Elkabash, I.A.; Salem, M.L.; Elshanshoury, M.; et al. MicroRNA signature in hepatocellular carcinoma patients: Identification of potential markers. Mol. Biol. Rep. 2020, 47, 4945-4953. [CrossRef]

47. Xue, X.; Zhao, Y.; Wang, X.; Qin, L.; Hu, R. Development and validation of serum exosomal microRNAs as diagnostic and prognostic biomarkers for hepatocellular carcinoma. J. Cell. Biochem. 2019, 120, 135-142. [CrossRef] [PubMed]

48. Liu, H.N.; Wu, H.; Chen, Y.J.; Tseng, Y.J.; Bilegsaikhan, E.; Dong, L.; Shen, X.Z.; Liu, T.T. Serum microRNA signatures and metabolomics have high diagnostic value in hepatocellular carcinoma. Oncotarget 2017, 8, 108810-108824. [CrossRef] [PubMed]

49. Zhuang, C.; Jiang, W.; Huang, D.; Xu, L.; Yang, Q.; Zheng, L.; Wang, X.; Hu, L. Serum miR-21, miR-26a and miR-101 as potential biomarkers of hepatocellular carcinoma. Clin. Res. Hepatol. Gastroenterol. 2016, 40, 386-396. [CrossRef] [PubMed]

50. Long, X.R.; Zhang, Y.J.; Zhang, M.Y.; Chen, K.; Zheng, X.F.S.; Wang, H.Y. Identification of an 88-microRNA signature in whole blood for diagnosis of hepatocellular carcinoma and other chronic liver diseases. Aging. 2017, 9, 1565-1584. [CrossRef]

51. An, Y.; Gao, S.; Zhao, W.C.; Qiu, B.A.; Xia, N.X.; Zhang, P.J.; Fan, Z.P. Novel serum microRNAs panel on the diagnostic and prognostic implications of hepatocellular carcinoma. World J. Gastroenterol. 2018, 24, 2596-2604. [CrossRef]

52. Amr, K.S.; Elmawgoud Atia, H.A.; Elazeem Elbnhawy, R.A.; Ezzat, W.M. Early diagnostic evaluation of miR-122 and miR-224 as biomarkers for hepatocellular carcinoma. Genes Dis. 2017, 4, 215-221. [CrossRef]

53. Bharali, D.; Banerjee, B.D.; Bharadwaj, M.; Husain, S.A.; Kar, P. Expression Analysis of MicroRNA-21 and MicroRNA-122 in Hepatocellular Carcinoma. J. Clin. Exp. Hepatol. 2019, 9, 294-301. [CrossRef]

54. Wang, Y.; Zhang, C.; Zhang, P.; Guo, G.; Jiang, T.; Zhao, X.; Jiang, J.; Huang, X.; Tong, H.; Tian, Y. Serum exosomal microRNAs combined with alpha-fetoprotein as diagnostic markers of hepatocellular carcinoma. Cancer Med. 2018, 7, 1670-1679. [CrossRef]

55. Motawi, T.K.; Shaker, O.G.; El-Maraghy, S.A.; Senousy, M.A. Serum MicroRNAs as Potential Biomarkers for Early Diagnosis of Hepatitis C Virus-Related Hepatocellular Carcinoma in Egyptian Patients. PLoS ONE. 2015, 10, e0137706. [CrossRef]

56. Yin, J.; Hou, P.; Wu, Z.; Wang, T.; Nie, Y. Circulating miR-375 and miR-199a-3p as potential biomarkers for the diagnosis of hepatocellular carcinoma. Tumour Biol. 2015, 36, 4501-4507. [CrossRef]

57. Elemeery, M.N.; Badr, A.N.; Mohamed, M.A.; Ghareeb, D.A. Validation of a serum microRNA panel as biomarkers for early diagnosis of hepatocellular carcinoma post-hepatitis C infection in Egyptian patients. World J. Gastroenterol. 2017, 23, 3864-3875. [CrossRef]

58. Hu, T.; Li, J.; Zhang, C.; Lv, X.; Li, S.; He, S.; Yan, H.; Tan, Y.; Lei, M.; Wen, M.; et al. The potential value of microRNA-4463 in the prognosis evaluation in hepatocellular carcinoma. Genes Dis. 2017, 4, 116-122. [CrossRef]

59. Shi, B.M.; Lu, W.; Ji, K.; Wang, Y.F.; Xiao, S.; Wang, X.Y. Study on the value of serum miR-106b for the early diagnosis of hepatocellular carcinoma. World J. Gastroenterol. 2017, 23, 3713-3720. [CrossRef]

60. Jiang, L.; Cheng, Q.; Zhang, B.H.; Zhang, M.Z. Circulating microRNAs as biomarkers in hepatocellular carcinoma screening: A validation set from China. Medicine 2015, 94, e603. [CrossRef]

61. Mohamed, A.A.; Ali-Eldin, Z.A.; Elbedewy, T.A.; El-Serafy, M.; Ali-Eldin, F.A.; AbdelAziz, H. MicroRNAs and clinical implications in hepatocellular carcinoma. World J. Hepatol. 2017, 9, 1001-1007. [CrossRef] [PubMed]

62. El-Hamouly, M.S.; Azzam, A.A.; Ghanem, S.E.; El-Bassal, F.I.; Shebl, N.; Shehata, A.M.F. Circulating microRNA-301 as a promising diagnostic biomarker of hepatitis C virus-related hepatocellular carcinoma. Mol. Biol. Rep. 2019, 46, 5759-5765. [CrossRef] [PubMed] 
63. Zhuang, L.P.; Meng, Z.Q. Serum miR-224 reflects stage of hepatocellular carcinoma and predicts survival. Biomed Res. Int. 2015, 2015, 731781. [CrossRef] [PubMed]

64. Shaheen, N.M.H.; Zayed, N.; Riad, N.M.; Tamim, H.H.; Shahin, R.M.H.; Labib, D.A.; Elsheikh, S.M.; Moneim, R.A.; Yosry, A.; Khalifa, R.H. Role of circulating miR-182 and miR-150 as biomarkers for cirrhosis and hepatocellular carcinoma post HCV infection in Egyptian patients. Virus Res. 2018, 255, 77-84. [CrossRef] [PubMed]

65. Sohn, W.; Kim, J.; Kang, S.H.; Yang, S.R.; Cho, J.Y.; Cho, H.C.; Shim, S.G.; Paik, Y.H. Serum exosomal microRNAs as novel biomarkers for hepatocellular carcinoma. Exp. Mol. Med. 2015, 47, e184. [CrossRef] [PubMed]

66. Guillerey, C.; Smyth, M.J. NK Cells and Cancer Immunoediting. Curr. Top. Microbiol. Immunol. 2016, 395, 115-145. [CrossRef] [PubMed]

67. Debes, J.D.; van Tilborg, M.; Groothuismink, Z.M.A.; Hansen, B.E.; Schulze Zur Wiesch, J.; von Felden, J.; de Knegt, R.J.; Boonstra, A. Levels of Cytokines in Serum Associate With Development of Hepatocellular Carcinoma in Patients With HCV Infection Treated With Direct-Acting Antivirals. Gastroenterology 2018, 154, 515-517.e513. [CrossRef]

68. Jiang, R.; Tan, Z.; Deng, L.; Chen, Y.; Xia, Y.; Gao, Y.; Wang, X.; Sun, B. Interleukin-22 promotes human hepatocellular carcinoma by activation of STAT3. Hepatology 2011, 54, 900-909. [CrossRef]

69. Lu, W.Q.; Qiu, J.L.; Huang, Z.L.; Liu, H.Y. Enhanced circulating transforming growth factor beta 1 is causally associated with an increased risk of hepatocellular carcinoma: A mendelian randomization meta-analysis. Oncotarget 2016, 7, 84695-84704. [CrossRef]

70. Ibrahim, G.H.; Mahmoud, M.A.; Aly, N.M. Evaluation of circulating Transforming growth factor-beta1, Glypican-3 and Golgi protein-73 mRNAs expression as predictive markers for hepatocellular carcinoma in Egyptian patients. Mol. Biol. Rep. 2013, 40, 7069-7075. [CrossRef]

71. Zhao, H.; Chen, Q.; Alam, A.; Cui, J.; Suen, K.C.; Soo, A.P.; Eguchi, S.; Gu, J.; Ma, D. The role of osteopontin in the progression of solid organ tumour. Cell Death Dis. 2018, 9, 356. [CrossRef]

72. Chimparlee, N.; Chuaypen, N.; Khlaiphuengsin, A.; Pinjaroen, N.; Payungporn, S.; Poovorawan, Y.; Tangkijvanich, P. Diagnostic and Prognostic Roles of Serum Osteopontin and Osteopontin Promoter Polymorphisms in Hepatitis B-related Hepatocellular Carcinoma. Asian Pac. J. Cancer Prev. 2015, 16, 7211-7217. [CrossRef]

73. Ge, T.; Shen, Q.; Wang, N.; Zhang, Y.; Ge, Z.; Chu, W.; Lv, X.; Zhao, F.; Zhao, W.; Fan, J.; et al. Diagnostic values of alpha-fetoprotein, dickkopf-1, and osteopontin for hepatocellular carcinoma. Med. Oncol. 2015, 32, 59. [CrossRef]

74. Vongsuvanh, R.; van der Poorten, D.; Iseli, T.; Strasser, S.I.; McCaughan, G.W.; George, J. Midkine Increases Diagnostic Yield in AFP Negative and NASH-Related Hepatocellular Carcinoma. PLoS ONE 2016, 11, e0155800. [CrossRef]

75. Shang, S.; Plymoth, A.; Ge, S.; Feng, Z.; Rosen, H.R.; Sangrajrang, S.; Hainaut, P.; Marrero, J.A.; Beretta, L. Identification of osteopontin as a novel marker for early hepatocellular carcinoma. Hepatology 2012, 55, 483-490. [CrossRef]

76. da Costa, A.N.; Plymoth, A.; Santos-Silva, D.; Ortiz-Cuaran, S.; Camey, S.; Guilloreau, P.; Sangrajrang, S.; Khuhaprema, T.; Mendy, M.; Lesi, O.A.; et al. Osteopontin and latent-TGF $\beta$ binding-protein 2 as potential diagnostic markers for HBV-related hepatocellular carcinoma. Int. J. Cancer 2015, 136, 172-181. [CrossRef]

77. Deng, H.; Fan, X.; Wang, X.; Zeng, L.; Zhang, K.; Zhang, X.; Li, N.; Han, Q.; Lv, Y.; Liu, Z. Serum pentraxin 3 as a biomarker of hepatocellular carcinoma in chronic hepatitis B virus infection. Sci. Rep. 2020, 10, 20276. [CrossRef]

78. Sadeghi, M.; Lahdou, I.; Oweira, H.; Daniel, V.; Terness, P.; Schmidt, J.; Weiss, K.H.; Longerich, T.; Schemmer, P.; Opelz, G.; et al. Serum levels of chemokines CCL4 and CCL5 in cirrhotic patients indicate the presence of hepatocellular carcinoma. Br. J. Cancer 2015, 113, 756-762. [CrossRef]

79. Lacal, P.M.; Graziani, G. Therapeutic implication of vascular endothelial growth factor receptor-1 (VEGFR-1) targeting in cancer cells and tumor microenvironment by competitive and non-competitive inhibitors. Pharmacol. Res. 2018, 136, 97-107. [CrossRef]

80. Mukozu, T.; Nagai, H.; Matsui, D.; Kanekawa, T.; Sumino, Y. Serum VEGF as a tumor marker in patients with HCV-related liver cirrhosis and hepatocellular carcinoma. Anticancer Res. 2013, 33, 1013-1021. [CrossRef]

81. Zekri, A.R.; Bahnassy, A.A.; Alam El-Din, H.M.; Morsy, H.M.; Shaarawy, S.; Moharram, N.Z.; Daoud, S.S. Serum levels of $\beta$-catenin as a potential marker for genotype 4/hepatitis C-associated hepatocellular carcinoma. Oncol. Rep. 2011, 26, 825-831. [CrossRef]

82. Naugler, W.E.; Sakurai, T.; Kim, S.; Maeda, S.; Kim, K.; Elsharkawy, A.M.; Karin, M. Gender disparity in liver cancer due to sex differences in MyD88-dependent IL-6 production. Science 2007, 317, 121-124. [CrossRef]

83. Shakiba, E.; Ramezani, M.; Sadeghi, M. Evaluation of serum interleukin-6 levels in hepatocellular carcinoma patients: A systematic review and meta-analysis. Clin. Exp. Hepatol. 2018, 4, 182-190. [CrossRef]

84. Shao, Y.Y.; Lin, H.; Li, Y.S.; Lee, Y.H.; Chen, H.M.; Cheng, A.L.; Hsu, C.H. High plasma interleukin-6 levels associated with poor prognosis of patients with advanced hepatocellular carcinoma. Jpn. J. Clin. Oncol. 2017, 47, 949-953. [CrossRef]

85. Li, Y.; Chen, G.; Han, Z.; Cheng, H.; Qiao, L. IL-6/STAT3 Signaling Contributes to Sorafenib Resistance in Hepatocellular Carcinoma Through Targeting Cancer Stem Cells. Onco Targets Ther. 2020, 13, 9721-9730. [CrossRef]

86. Liu, X.; Chi, X.; Gong, Q.; Gao, L.; Niu, Y.; Cheng, M.; Si, Y.; Wang, M.; Zhong, J.; Niu, J.; et al. Association of serum level of growth differentiation factor 15 with liver cirrhosis and hepatocellular carcinoma. PLoS ONE 2015, 10, e0127518. [CrossRef] 
87. Wischhusen, J.; Melero, I.; Fridman, W.H. Growth/Differentiation Factor-15 (GDF-15): From Biomarker to Novel Targetable Immune Checkpoint. Front. Immunol. 2020, 11, 951. [CrossRef]

88. Farvardin, S.; Patel, J.; Khambaty, M.; Yerokun, O.A.; Mok, H.; Tiro, J.A.; Yopp, A.C.; Parikh, N.D.; Marrero, J.A.; Singal, A.G. Patient-reported barriers are associated with lower hepatocellular carcinoma surveillance rates in patients with cirrhosis. Hepatology 2017, 65, 875-884. [CrossRef] [PubMed] 